\title{
THE SOCIO-PROFESSIONAL STATUS OF PHYSICAL EDUCATION TEACHERS IN PORTUGAL - A QUALITATIVE APPROACH
}

\author{
António Gomes Ferreira ${ }^{1}$ and José António Moreira ${ }^{2}$
}

${ }^{1}$ Faculty of Psychology and Educational Sciences, Coimbra, Portugal

${ }^{2}$ Department of Education and Distance Learning, Porto, Portugal

ORIGINAL SCIENTIFIC PAPER

DOI: 10.5550/sgia.110701.en.001G

COBISS.BH-ID: 2100504

UDC: $371.124: 796(469)$

\section{SUMMARY}

Despite some worth mentioning initiatives, Physical Education teaching in Portugal was only unveiled and recognised at a later stage by others than the ones directly involved in it. In fact, during most of the $20^{\text {th }}$ century, both the subject and the teachers were clearly considered to have a peripheral status, particularly when compared to their professional peers. Considering the changes in the last decades, we found it pertinent to analyse how these teachers perceive the status that is assigned to them by teachers of other subjects, and also by their students. For the purpose of this analysis, we used a qualitative methodology in our study focused on a group of fifteen teachers with varied degrees in Physical Education, and graduated from some of the most distinguished schools in Portugal since the 1940s until the end of the 20th century. We concluded that there could be made a definition to a certain extent, regarding what the other teachers think about the status of Physical Education teachers. Some of the teachers, namely those graduated from institutes, ISEF (College of Physical Education), realise that their fellow teachers do not recognise their true value and treat them as the "poor relatives" of education. Nevertheless, there are those who perceive and recognise their value and treat them as equals. More consensual, however, seem to be their perceptions about the opinion of students and staff, as our study tends to show that Physical Education teachers feel that they assign them an identical status to that of teachers of other subjects.

Key Words: physical education; teachers, socio-professional status.

\section{INTRODUCTION}

We can say with some certainty that the process of professionalisation of Physical Education teachers and professional awareness only really began in 1940 with the creation of the National Institute of Physical Education (INEF - Portuguese acronym for Instituto Nacional de Educação Física). Indeed, important changes operated within the INEF decisively contributed to the creation of an organisation and professional identity in the field of Physical Education. Since then, there has been uniformity in the profession, through the unification of recruitment, certification and unique training model, and the systematization of knowledge by trying to integrate the different training components (scientific, pedagogical and pedagogical-di- dactic) into the three year course. And, more importantly, there were teachers whose sole mission and profession were the teaching of the Physical Education, because until then the post was mainly for doctors or army officers, who saw this as an ancillary profession (Gomes, 1991).

However, despite the creation of this professional organisation, these professionals were poorly evaluated in the forties, fifties and sixties, bearing in mind the type of training they had and the inequalities they were subject to compared to the teachers of other studies. For a long time, a number of professionals defended that Physical Education teachers should be equivalent to other secondary education teachers, considering not only their higher education qualifications as well as their responsibilities in terms of providing educational 
training to young students. In the INEF newsletter, referring to the Physical Education teachers, João de Barros noted that their fees were "about half of the salary of colleagues from other subject groups", and, in his opinion, about $50 \%$ of what these teachers would need to live on $(1959$, p. 32), an unfair situation because there was "no educational or scientific reason that could ever justify the lower status of physical education and music, and its teachers, in the national school organisation" (ibidem, p. 33).

In the early sixties, this inferiority was still was a reality, as teachers of Physical Education were barred from being hired as employees and, at best, they were contracted workers in the framework of Physical Education. Thus, the difference was not only in terms of wages but also in the type of labour relations that these teachers had. In fact the only reason invoked to justify the different treatment of teachers of the so called "noble" subjects and those of Physical Education resided in the non-university degree status of Physical Education.

However, the attempt to expand the number of teaching staff of Physical Education was made through the creation of Schools of Physical Education Instructors (at the EIEF - Portuguese acronym for Escolas de Instrutores de Educação Física). These shorter courses had been contested by many professionals of the field because, in their opinion, they represented a setback in the training process that had been outlined since the early forties. Considered as teachers "made under pressure", trained in only two years, these shorter courses incorporated certain individuals of more modest social origin and more women, threatened the requalification of Physical Education, created instability and a image of easiness that shook the spirit of professional organization, forming a division within the profession and giving rise to conflict around the issues of hierarchy (Crespo, 1976).

The situation of inferiority of Physical Education professionals compared to colleagues of other areas persisted for many years, and the government felt there was no need to do justice to a class that had proved, more than enough, its competence (Rosário, 1996). Indeed, in the first half of the seventies, this inferiority was still quite evident, and Physical Education was unable to assert itself as an important subject among other teachers and among the Portuguese in general. Since 1974, the situation has improved with the integration of training in Physical Education in university higher education and the publication of a series of diplomas that valued the importance of teaching Physical Education (Brás, 1996) in the education system. Although the government recognised this, the Physical Education teachers, according to some authors, continued to be underestimated by a relatively large bracket of "national intelligence", even if, based on its training and specific tasks, it could be included in this bracket (Bento, 1986; Crespo, 1992). In fact, although it was not dubbed as an ancillary discipline, Physical Education was kept out of the core humanistic, scientific, aesthetic and modern values (Carvalho, 2002), which hindered the recognition of its importance. Thus, although in the early years of the eighties the qualified Physical Education teachers "relished" the university status assigned to their training, they had not yet been given the desired widespread social recognition (Moreira \& Ferreira, 2011).

At the end of the decade, a number of situations emerged that contributed to the differentiation of the professional status and to the complex situation of Physical Education as a school subject and as an area of knowledge. Real or perceived, this crisis was observed at a time when there were several courses in the field of Physical Education and Sports, some lacking the desired quality, bringing with them a certain conceptual, methodological and ethical division and disorientation (Januário, 1995). In fact, the emergence of new courses and new institutions for training teachers of Physical Education, some belonging to the subsystem of public higher university education and others to the polytechnic institutes, and others to private institutions gave rise to tensions and conflicts resulting from different backgrounds of knowledge and prestige. Although those with degrees from public universities and those with degrees from other institutions were all teachers of Physical Education, their status and legitimacy were different, contributing to the decline of the profession. It was, therefore, based on this context that we sought to develop a study to examine how the Physical Education teachers perceive the importance that teachers of other subject groups and students assign to them. 


\section{METHODS}

In this study, we intend to basically analyse how a group of Physical Education teachers in Portuguese primary education $\left(7^{\text {th }}, 8^{\text {th }}\right.$ and $9^{\text {th }}$ year of schooling) and secondary education schools $\left(10^{\text {th }}\right.$, $11^{\text {th }}$ and $12^{\text {th }}$ year of schooling) views the importance that teachers of other subject groups and school students assign to them. The nature of this research led us to consider a qualitative study where the direct speech submits to an interpretative logic, that in framing and explaining the position of the interviewed teachers, intends to describe how Physical Education teachers relate within their subject group in the current Portuguese school context. Situating ourselves, therefore, within the framework of a non-positivist and interpretative paradigm of phenomenological and ideographic nature (Cohen \& Manion, 1990) we resort, in this research, to a methodology of qualitative nature that places the emphasis on upgrading the "person" as a subject of knowledge capable of reflecting, rationalising, communicating and interacting (Pujadas Munoz, 1992; Silverman, 2000). Aiming to stimulate the emergence of study data, we resorted to the use of semi- directed interviews, and to analyse the data from this interview we used a research technique that encodes the apparently disordered statements: the analysis of contents (Bardin, 1977; Ferrarotti, 1986; Krippendorf, 1980; Vala, 1986).

This technique consists in the systematic analysis of a text (Ferrarotti, 1986) allowing us to identify the most repeated subjects as well as the mental associations that gave rise to it. To achieve the analysis of contents, we adopted the methodology and the procedures defined by Bardin (1995) and Vala (1986): the organisation of the analysis, the coding focused on the content guided by the identification of subjects, the grouping, the inference and the interpretation.

We began this analysis with a drifted reading of all the interviews, aiming to line up the common subjects and detect particularities according to the specific respondent. Later, we began the coding process, which involved the identification of the subjects or definition of the categories of analysis of the units, favouring enumeration or choice of the counting rules, classification and aggregation, meaning, the choice of the categories. After defining the categories and organising "clippings" and "gluing", we moved on to systematising the emergent groups, aiming to respect the exhaustive rule defended by Bardin (1995), which considers all the elements of the corpus.

Considering all the interviews of the group and comparing the contents, we separated all the records of the corpus into paragraphs and sequentially numbered them according to the alignment of the interviews.

In order to organise the information into a perceivable structure, we opted to codify the data using only three letters (without repeating codes to avoid problems of indexation in computer processing), ie. the initials, the three first letters of the word, or a set of three significant letters.

Finally, based on the representation of the records, we analysed the inference and interpretation of the data in the interviews. In this respect, the results are nothing more than a systematisation of the descriptions, the sense of which we hope to understand by organising them into categories of analysis chosen by us, having as main objective their interpretation.

\section{TABLE 1}

Study sample

\begin{tabular}{ll}
\hline \multicolumn{1}{c}{ Codes of interview } & \multicolumn{1}{c}{ Institutions of Initial Formation } \\
\hline E2, E13, E14 & Instituto Nacional de Educação Física (INEF) \\
\hline E10, E12 & Escola Instrutores de Educação Física (EIEF) \\
\hline E1, E4, E7, E8, E10, E11 & Institutio Superior de Educação Física (ISEF) \\
\hline E3, E5, E6, E9, E15 & Faculdades de Desporto de Educação Física (FAC) \\
\hline
\end{tabular}

Our sample consisted of a group of fifteen interviews to teachers (Table 1) with different initial training in Physical Education, taken at well known institutions of our country during the twentieth century: the National Institute of Physical Education (INEF - Portuguese acronym for Instituto 
Nacional de Educação Física), created in 1940; the Schools of Physical Education Instructors; the Higher Institutes of Physical Education in Lisbon and Porto; and the Faculties of Science, Sports and Physical Education, created in the early nineties.

After deciding to study this group of professionals, we selected it in a non-random way without looking for a "representative" sample, given the qualitative nature of the methodology. This selection sought to ensure the greatest possible diversity of experience and personal characteristics and was based on initial training courses (training institutions). With this procedure, we wanted our sample to be made up of teachers who had different training courses in different time periods, with different lengths of service and career positions, in order to come close to the concept of maximum variation sample.

\section{RESULTS AND DISCUSION}

As mentioned above, we do intend to consider in our analysis pertaining to the recognition of the status of Physical Education teachers the diversity of initial training of the individuals who made up this teaching group in the first decade of the $21^{\text {st }}$ century. The central idea of this study is that the perception of the status of Physical Education teachers is to some extent linked to their initial training and to the way in which these teachers relate their projections from this training with other colleagues in the same area and with teachers of others subjects as well as with students.

In this sense, we tried to find out how Physical Education teachers coming from different schools of training perceive the importance that teachers of other groups and students assign to them. To this end, we will present the information from the interviews in tables, in order to illustrate the relevance of some of their opinions. We think that choosing this organisation model of information that allows us to study the representations of teachers in a systematic and analytical way will allow a more adequate view of the general representation of their perceptions. The records pertaining to this dimension were marked with the expressions of Full Approval (+), Full Fail (-) and Balanced (+/-).

By induction, based on the responses from teachers, it was possible to fit in this dimension, seventy eight records, the categories of Teachers from Other Subject Groups (PGD - Portuguese acronym for Professores de outros Grupos Disciplinares), meaning how teachers perceive the importance that teachers of other subject groups assign to them; Students (ALU - Portuguese acronym for Alunos), meaning how teachers perceive the importance that students assign to them.

For the first category, teachers from other subject groups and with respect to the classification of the records, we found that out of the twenty five records, eleven have a positive sign, three show some indecision and eleven have a negative sign, revealing a balance of opinion that these teachers have about this recognition from fellow students. While some perceive that other teachers do not recognise their value, treating them as "poor relatives" of teaching, as belonging to a "second line" of educators, others perceive that there is already recognition of their value and equal treatment.

In effect, several studies (Armour \& Jones, 1998; Hendry, 1975; Templin \& Schempp, 1990) prove the "peripheral" situation of Physical Education teachers, which are disadvantaged in terms of rewards and support to their work, or in terms of perception that other teachers have; so these perceptions underline usually the non-academic, antiintellectual and peripheral nature of the subject they teach (Williams, 1981).

With regard to the opinions of teachers with degrees from INEF and EIEF, we found four records in this subcategory, all with a positive sign, which reveals the existence of a perception of equal status, although some teachers do admit that some of the older colleagues still find it difficult to treat them in the same way.

Respondent -E13- (Table 2), as we can see in the record shown, feels that although the situation is much better than thirty years ago, there are still teachers who look at Physical Education in a different way, thinking that these teachers are professional entertainers.

Respondent -E2- also refers that from the moment when "[...] teachers of other areas realised that Physical Education teachers also had university training, they began to show different behaviour" (UR 8).

It seems clear that the issue of initial training is important. Respondent -E14- has no doubt that this was a problem that affected the recognition of the status of the Physical Education group, saying that: " [...] the lack of training of some Physical Education teachers made people look at the subject with some disdain [...] But now I find that things are much better, and there 
are fewer teachers with this negative view [...?” (UR 69). In fact, this teacher alerts us to an important issue at the professional status level, related to the lack of training of some teachers who taught in schools until the eighties of the 20th century. At that time, the number of Physical Education teachers increased to address the lack of teachers due to the expansion of schools then underway. People were recruited without having proper training or with very short training; this was the case of the Physical Education instructors. This situation eventually threatened the qualification system of Physical Education in schools and brought about instability to the possible construction of interests common to the Physical Education teachers (Carvalho, 2002). In fact, the work developed by the teachers with degrees from the INEF and later from its successor university institutions was hindered by teachers without proper training who could hardly understand and keep up with the effort of valuing and dignifying Physical Education in Portuguese schools.

TABLE 2

Teachers of other subject groups (INEF/EIEF)

\begin{tabular}{cccc}
\hline S UR Marking & Record \\
\hline E13 $65 \quad+\quad \begin{array}{l}\text { Now I find that things are much better, but there are still some teachers, especially } \\
\text { the older ones, that look at Physical Education a little differently, thinking that we } \\
\text { are still professional entertainers. They think that we do not prepare the lessons and } \\
\text { that they do not follow any structure. It's just running and jumping [...] }\end{array}$ \\
\end{tabular}

Legend: S - Codes of interview; UR - Unit of register; + - Full Approval.

In fact, the perceptions of teachers trained at the ISEFs seem to be different from those trained at INEF/EIEF. Of the eleven existing records in this subcategory, seven of them are negative, three show some indecision and only one is positive, which shows that these teachers have the perception that they are still seen as the "poor relatives" of teaching and there are still many teachers of other subjects do not assign equal importance to the efforts of Physical Education teachers. To prove this, we have the testimony of respondent -E4- who states, as we can see in Table 3 (first record), that the treatment given by the school board confirms this inferiority.

Respondent-E1- also emphasises that Physical Education teachers and the subject itself lack recognition, and tries to find an explanation for this: "I do not know if maybe we, as teachers of Physical Education, are guilty, but my idea is that to some extent we are guilty, because maybe we should be more careful in the way we manage our pedagogical activity [...]" (UR 2). That is, in the $21^{\text {st }}$ century, teachers trained at ISEFs understand that Physical Education teachers are not only less valued in relation to teachers of other subjects, but this can also be the result of poor pedagogical awareness of the physical education teachers themselves.
Respondents -E7- and -E11- show the same position. While the latter states that they are still regarded as "second line" teachers, the former reinforces the opinion of -E4- with regard to the issue of assessment of the subject, pointing out that "teachers in formal and informal conversations say that Physical Education is important, but when Physical Education teachers try to be consistent and give fair grades according to student performance, they are often 'forced' to change the grades allegedly because this area is not so important and they can only spoil the students' grade averages" (UR 36). This position, shown by some teachers of other areas at review meetings and described by respondent-E7-, shows that there is still some prejudice from the late sixties that the subject itself is not of an academic background. At that time, and despite the changes taking place within the subject, the status of Physical Education and its teachers and the traditional noble subjects and their teachers was not entirely equivalent. But, so it seems, at the end of the first decade of the $21^{\text {st }}$ century the subject is still seen as inferior. The position of respondent -E10- reflects this reality a bit, when he says: "Physical Education is an important subject, because it contributes to well-being and improves the physical condition of children, but then again it is not assigned the same importance as the one assigned to History, Mathematics, etc [...]" (UR 54). The only record with a clearly posi- 
tive trend is that of respondent -E8-, shown in Table 3 , indicating that he has an identical status to that of other teachers, because of his quality training and good practices. But it is not clear that this kind of recognition can be generalised within the majority of the teachers of his field of expertise. It may well be that the others consider him as an equal in that school, but this may not be the feeling of teachers of other subjects about the groups of teachers of Physical Education in the country or even in a specific region.

With regard to the perceptions of teachers graduating more recently, we found eight records in this subcategory, six positive ones and only two negative ones, which seems to reveal, contrary to the position of those that received training at the ISEFs, that nowadays they feel that their status is identical to the ones of other teachers, although some still differentiate the subjects of academic and of non-academic background, dubbing the Physical Education teacher as "gym" teacher.
This is the observation of respondent-E6- who states, as we can see in the first record in Table 4, that fortunately those conservative teachers who said that "gym teachers were great for teaching tumbles and jumps" are not that many anymore.

Some of the teachers interviewed said they felt downgraded when they were called gym teachers. Influenced precisely by the expression "gym teacher", respondent -E9- feels the same as the previous respondent, saying that: "[...] nowadays, the status is the same, but it was not always so. Until about ten or fifteen years ago, we were dubbed gym teachers" (UR 45).

Finally, respondent -E5- feels he is a privileged teacher, justifying the parity treatment with the fact that "in addition to being a Physical Education teacher", he coordinates the department, the School Sports and is a class director, and so he believes this is why "the other teachers recognise my performance as I am constantly working at school" (UR 24). But like all other teachers interviewed, he is aware that some still "[...] do not consider Physical Education and its teachers as having an identical status" (UR 26).

TABLE 3

Teachers of other subject groups (ISEF)

\begin{tabular}{cccl}
\hline S & UR & Marking & \multicolumn{1}{c}{ Record } \\
\hline E4 & $18 \quad-\quad \begin{array}{l}\text { Some teachers still look at us as if we were the poor relatives. And what I'm about } \\
\text { to tell you confirms it. The Chairman of the Executive Board told us one day: "You } \\
\text { can change the evaluation criteria, but they will not be accepted in the Teaching } \\
\text { Standards Committee, because I do not have a classroom to give you for the tests". }\end{array}$ \\
E8 & $40 \quad+\quad \begin{array}{l}\text { Yes! It seems to me that from the moment my colleagues realised that we also have } \\
\text { a higher education degree and that our practices are not what they used to be, they } \\
\text { changed their attitude a bit. But there are always exceptions [... }\end{array}$ \\
\hline
\end{tabular}

Legend: S - Codes of interview; UR - Unit of register; + - Full Approval; - - Full Reprobation.

TABLE 4

Teachers of other subject groups (FCDEF)

\begin{tabular}{cccl}
\hline S & UR Marking & \multicolumn{1}{c}{ Record } \\
\hline E6 & $31 \quad+\quad \begin{array}{l}\text { The mentality of teachers from other areas is already changing. We used to be the } \\
\text { gym teacher who told students to do a few tumbles and jumps; now we are the te- } \\
\text { achers of Physical Education. But there are still some, especially the older ones, who } \\
\text { still think we're the gym teacher. }\end{array}$ \\
E3 $14 \quad-\quad \begin{array}{l}\text { I'm treated differently by some teachers, and it's funny because this treatment has } \\
\text { changed over the years; the idea of the gym teacher has changed, but still there are } \\
\text { those who tell jokes, but because their words don't matter, I usually do not comment. }\end{array}$
\end{tabular}

Legend: S - Codes of interview; UR - Unit of register; + - Full Approval; - - Full Reprobation. 
From the opinions of the teachers interviewed from the Higher Institutes or from the Faculties of Sports Sciences and Physical Education, it is clear that, despite changes in recent decades, there are still some teachers from other subject areas that do not assign the same importance to Physical Education and its teachers as they do to other more intellectual subjects.

Regarding the category of Students and the classification of records, we found that out of the fifteen records, eleven are positive, one shows some indecision, and only three are negative, which reveals that students have the same perception of an identical status for Physical Education teachers and for teachers of other subjects. However, the majority of records show that the students in our study slightly confuse the issue of status with the issue of liking the subject.

TABLE 5

Students (INEF/ EIEF)
On the other hand, looking at the opinions of the teachers trained at INEF and EIEF, we found in this category four records, three of which are positive and one shows some uncertainty regarding the above mentioned aspect, which seems to account for the notion of having an identical status. As respondent-E2- states, in the record in Table 5 , since the weight of the subject began to influence the students' assessment, they have begun to pay some attention to it.

Other respondents trained at INEF, -E13- and -E14-, although not discussing this in great detail, are under impression that students recognise that the status of the Physical Education teacher is identical to the one of teachers of others subjects. In turn, the teacher trained at EIEF, having doubts in this respect, states that "students like the subject, but she doesn't know if they understand whether it has the same status" (UR 63).

\begin{tabular}{cccc}
\hline S UR Marking & \multicolumn{1}{c}{ Record } \\
\hline E2 $10+\quad \begin{array}{l}\text { Since this subject influences the grade average, students no longer skip so many } \\
\text { classes and are beginning to pay a little more attention to it. This also was a struggle } \\
\text { of the INEF, who always fought to bring all the subjects on a par. In fact, there is } \\
\text { evidence that physical education is very beneficial not only from the physical point } \\
\text { of view, but also from the psychological point of view, and can help increase aca- } \\
\text { demic performance. }\end{array}$ \\
\hline
\end{tabular}

Legend: S - Codes of interview; UR - Unit of register; + - Full Approval.

One of the statements made by this teacher takes us to the focal point of the interpretation of the recorded responses. She is almost certain that students enjoy Physical Education, but doubts that they place it at the same level as the other subjects.

Regarding the opinion of the teachers trained at ISEF, the results are more balanced. Of the six existing records in this subcategory, four are positive and two are negative, but if we are to look closer at these records, we will see that these teachers find it difficult to distinguish if the feeling for this subject is the same. In fact, we believe that enjoying Physical Education and liking the teacher does not necessarily mean recognising that the teacher has the same professional status.

In any case, there is also a perception among Physical Education teachers that students do not always assign great importance to their efforts. Respondent -E11- mentions, as we can see in the second record in Table 6 , that some students do not assign any importance to the subject or to Physical Education teachers. In this regard, respondent-E1-, seems to have a clear-sighted view, because he has the feeling that although his students like him and his subject, they do not assign as much importance to him and the subject as they do to other subjects and their teachers.

As far as the perceptions of teachers trained more recently are concerned, we found in this category five records, four of which are positive and only one is negative. These records are quite identical to the records of teachers from the ISEFs, and also reveal some misunderstandings on the issue of status and liking the subject. The statement of respondent-E6- is quite clear on this, as we can see in the first record in Table 7. The opinions of respondents -E3- and-E5- point in the same direction. Some of the interviews are more obvious. 
Respondent -E15-, as we can see in the second record, in the same table, shows that although students like the subject, they do not assign it the same importance.

TABLE 6

Students (ISEF)

\begin{tabular}{cccl}
\hline S & UR & Marking & Record \\
\hline E7 & 37 & + & Students even enjoy Physical Education and find their teachers "very cool". \\
E11 & 58 & - & $\begin{array}{l}\text { I have had students telling it "to my face" that I could grade them as I please, beca- } \\
\text { use it did not count at all. So, when they say this, it means that they feel the same } \\
\text { about its importance. }\end{array}$ \\
\hline
\end{tabular}

Legend: S - Codes of interview; UR - Unit of register; + - Full Approval; - - Full Reprobation.

TABLE 7

Students (FCDEF)

\begin{tabular}{cccc}
\hline S & UR & Marking & Record \\
\hline E6 & 33 & + & Students recognise our work because normally this is the class they enjoy the most. \\
\hline E15 & 74 & - & The students, I don't think so, although, generally speaking, they like the subject. \\
\hline
\end{tabular}

Legend: S - Codes of interview; UR - Unit of register; + - Full Approval; - - Full Reprobation.

Sometimes, too, these respondents tend not to distinguish between importance, difficulty, evaluation and status. The statement of respondent -E9, saying that "students begin to be aware of its importance, because they experience its strictness' first-hand" (UR 596), seems to reflect this vague concept. Without ignoring the fact that the issue of power is relevant in this sense of status, we believe it should not be interpreted only in terms of greater "strictness" of Physical Education teachers.

\section{CONCLUSION}

The teaching of Physical Education in Portugal took a long time to be integrated in public schools and become credible compared to other school subjects. In fact, Physical Education and its teachers were less valued than other subjects and teachers of other areas in the school system, for almost the entire $20^{\text {th }}$ century. In fact, only with the training provided by INEF was there more uniformity in the profession, with a single training model, at least until the creation of Schools of Physical Education Instructors. However, we must always bear in mind that the changes were slow. Therefore, until the mid-seventies of the $20^{\text {th }}$ century, the professional status of Physical Education teachers is characterised by not being on a par with the teachers of the more intellectual subjects.

From the analysis of the interviews, summarised in the previous pages, we can see that there are some aspects that involve more consensus or more attention than others. One of the more consensual aspects relates to the fact that most Physical Education teachers believe that their students recognise their value as teachers of this subject. However, the analysis of these results must be made with some reserve, because it seems that the respondents in our study sometimes confuse the professional status with the mere fact of liking the subject. The fact that Physical Education teachers have the perception that students enjoy and value the subject they teach is not the same as assigning the same importance to those of more intellectual bias.

Less consensual are the results referring to the importance that the Physical Education teachers believe are assigned to them by the teachers of other subject groups. Indeed, in the first case, while some teachers, especially those with ISEF degrees, have the perception that professional colleagues do not recognise their value and treat them as "the poor relatives" of teaching or as if they belong to a "second 
line" of educators, there are others who perceive that their value is recognised and demonstrate parity treatment. Note that these results are consistent with recent studies developed by Martins (2010) and Cortesão (2010), pointing in the same direction. Martins, for example, found that $42 \%$ of the teachers from other subject groups considered it less harmful to miss a Physical Education class than miss a class in another subject. This means that the teaching of Physical Education is not considered as important as the more classical and intellectual subjects, so then it is normal that its teachers sometimes feel that they are not always as reputed as others that teach other subjects. In any case, much has changed in the last few decades of the 20th century and the first decade of the 21 st century. Today, Physical Education teachers are part of a legal framework and have responsibilities as any another teacher of any another professional group. Some even occupy higher ranks in school organisation. But this study also reveals that changing the legal framework is not enough to change the perception of a professional group. Some of the teachers interviewed were well aware of this and did not overlooked the fact that some of their peers still nourish an idea of inferiority of Physical Education and its teachers.

\section{REFERENCES}

Armour, K., \& Jones, R. (1998). Physical Education Teacher's Lives and Carreers. London: Farmer Press.

Bardin, L. (1995). Análise de Conteúdo (Content Analysis). Lisboa: Edições 70.

Barros, J. (1959). Da Situação do Professor de Educação Física (The Situation of the Physical Education Teacher). Boletim INEF, 1 (XX), $32-33$.

Bento, J. (1986). Acerca do papel do professor de Educação Física (About the Role of the Physical Education Teacher). Horizonte, 13, 3-7.

Barás, J. (1996). Metamorfoses na formação de professores de Educação Física (Metamorphosis in the Training of Physical Education Teachers). Boletim SPEF, 14, 47-54.

Carvalho, L. (2002). Sobre o status da disciplina da Educação Física na década de sessenta: fragmentos de um estudo histórico-organizacional (On the status of the physical educati- on subject in the sixties: fragments of an historical-organizational study). Boletim SPEF, 21/22, 55-85.

Cohen, L., \& Manion, L. (1990). Métodos de Investigation Educativa (Methods of Educational Research). Madrid: La Muralla.

Cortesão, M. (2010). Clima Escolar, Participação

Docente e Relação entre os Professores de Educação

Fisica e a Comunidade Educativa (School Environment, Teacher Participation and Relation between Physical Education Teachers and the Educational Community). Unpublished master thesis. University of Coimbra, Faculty of Psychology and Education Sciences.

Crespo, J. (1976). A formação de professores de Educação Física. Alguns dados históricos (Physical Education Teacher Training. Some historical data). Ludens, 1(1), 29-36.

Crespo, J. (1992). A Educação Física. A

Reestruturação de uma identidade (Physical Education. Restructuring an identity). Horizonte, 48, 217-222.

Ferrarotti, F. (1986). Sociologia (Sociology). Lisboa: Editorial Teorema.

Gomes, R. (1991). Poder e Saber sobre o Corpo - A Educação Física no Estado Novo (19361945) (Power and Knowledge about the Body - Physical Education during the $»$ Estado Novo«). Boletim SPEF, 2/3, 109-138.

Hendry, L. (1975). Survival in a marginal role: the professional identity of the physical education teacher. British Journal of Sociology, 26(4), 465-476.

Januário, C. (1995). Um conceito para a Educação Física (A concept for Physical Education). Horizonte, 66, 203-207.

Krippendorf, K. (1980). Content analysis. London: Sage.

Martins, I. (2010). Clima de Escola, Participação e Identidade- Um olhar sobre a disciplina e o professor de Educação Física. Dissertação de Mestrado

(School Environment, Participation and Identity - A glance at the physical education subject and teacher). Unpublished master thesis. University of Coimbra, Faculty of Psychology and Education Sciences.

Moreira, J., \& Ferreira, A. (2011). The self-esteem of the teachers of Physical Education in Portugal. Online Proceedings European Society for the Systemic Innovation of Education, 
Towards Systemic Innovation of Education. Leuven: ESSIE Annual Assembly, 55-59.

Pujadas Munoz, J. (1992). El método biográfico: el uso de las historias de vida en ciências sociales (The biographical method: the use of life stories in social sciences). Madrid: CIS.

Rosário, A. (1996). O Desporto em Portugal. Reflexo e Projecto de uma Cultura (Sports in Portugal. Reflection and Project of a Culture). Lisboa: Instituto Piaget.
Silverman, D. (2000). Doing Qualitative Research. London: Sage.

Templin, T., \& Schempp, P. (1990). The problematic nature of a career in a marginal subject. Journal of Education for Teaching, 16, 3-28.

Vala, J. (1986). A análise de conteúdo (Methodology of Social Sciences). Content Analysis in A. Silva and J. Pinto (eds.), Metodologia das Ciências Sociais. Porto: Edições afrontamento.

Williams, E. (1981). The Physical Education Specialist - problem of definition. Bulletin Physical Education, 63(3).

Received: May 10, 2011

Accepted: Juny 7, 2011

Correspodence to: António Gomes Ferreira, PhD

Rua do Colégio Novo Apartado 6153

3001-802 Coimbra Portugal

Phone: 00351239851450

Fax: 00351239851465

E-mail: antonio@fpce.uc.pt 